\title{
Front Matter: Volume 8342
}

"Front Matter: Volume 8342," Proc. SPIE 8342, Behavior and Mechanics of Multifunctional Materials and Composites 2012, 834201 (8 May 2012); doi: 10.1117/12.964055

SPIE Event: SPIE Smart Structures and Materials + Nondestructive Evaluation and SPIE. Health Monitoring, 2012, San Diego, California, United States 


\title{
PROCEEDINGS OF SPIE
}

\section{Behavior and Mechanics of Multifunctional Materials and Composites 2012}

\author{
Nakhiah C. Goulbourne \\ Zoubeida Ounaies \\ Editors \\ 12-15 March 2012 \\ San Diego, California, United States \\ Sponsored by \\ SPIE \\ Cosponsored by \\ American Society of Mechanical Engineers (United States) \\ Cooperating Organizations \\ Intelligent Materials Forum (Japan) \\ Jet Propulsion Laboratory (United States) \\ National Science Foundation (United States) \\ Published by \\ SPIE
}

Volume 8342 
The papers included in this volume were part of the technical conference cited on the cover and title page. Papers were selected and subject to review by the editors and conference program committee. Some conference presentations may not be available for publication. The papers published in these proceedings reflect the work and thoughts of the authors and are published herein as submitted. The publisher is not responsible for the validity of the information or for any outcomes resulting from reliance thereon.

Please use the following format to cite material from this book:

Author(s), "Title of Paper," in Behavior and Mechanics of Multifunctional Materials and Composites 2012, edited by Nakhiah C. Goulbourne, Zoubeida Ounaies, Proceedings of SPIE Vol. 8342 (SPIE, Bellingham, WA, 2012) Article CID Number.

ISSN 0277-786X

ISBN 9780819489999

Published by

SPIE

P.O. Box 10, Bellingham, Washington 98227-0010 USA

Telephone +1 3606763290 (Pacific Time) · Fax +1 3606471445

SPIE.org

Copyright (C) 2012, Society of Photo-Optical Instrumentation Engineers

Copying of material in this book for internal or personal use, or for the internal or personal use of specific clients, beyond the fair use provisions granted by the U.S. Copyright Law is authorized by SPIE subject to payment of copying fees. The Transactional Reporting Service base fee for this volume is $\$ 18.00$ per article (or portion thereof), which should be paid directly to the Copyright Clearance Center (CCC), 222 Rosewood Drive, Danvers, MA 01923. Payment may also be made electronically through CCC Online at copyright.com. Other copying for republication, resale, advertising or promotion, or any form of systematic or multiple reproduction of any material in this book is prohibited except with permission in writing from the publisher. The CCC fee code is 0277-786X/12/\$18.00.

Printed in the United States of America.

Publication of record for individual papers is online in the SPIE Digital Library.

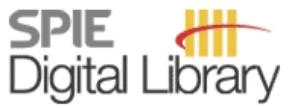

SPIEDigitalLibrary.org

Paper Numbering: Proceedings of SPIE follow an e-First publication model, with papers published first online and then in print and on CD-ROM. Papers are published as they are submitted and meet publication criteria. A unique, consistent, permanent citation identifier (CID) number is assigned to each article at the time of the first publication. Utilization of CIDs allows articles to be fully citable as soon as they are published online, and connects the same identifier to all online, print, and electronic versions of the publication. SPIE uses a six-digit CID article numbering system in which:

- The first four digits correspond to the SPIE volume number.

- The last two digits indicate publication order within the volume using a Base 36 numbering system employing both numerals and letters. These two-number sets start with $00,01,02,03,04$, $05,06,07,08,09,0 A, 0 B \ldots 0 Z$, followed by 10-1Z, 20-2Z, etc.

The CID number appears on each page of the manuscript. The complete citation is used on the first page, and an abbreviated version on subsequent pages. Numbers in the index correspond to the last two digits of the six-digit CID number. 


\section{Contents}

ix Conference Committee

\section{SESSION 1 FERROELECTRIC MATERIALS}

834204 Plane wave dynamics in multiferroic materials using Maxwell's equations and equation of motion [8342-03]

S. M. Keller, G. P. Carman, Univ. of California, Los Angeles (United States)

834205 Quadrupole effects on modeling piezoelectric and ferroelectric materials [8342-04]

W. S. Oates, H. Wang, The Florida State Univ. (United States)

\section{SESSION 2 ACTIVE COMPOSITES I}

834206 Ultra high energy density nanocomposite capacitors using surface-functionalized $\mathrm{BaTiO}_{3}$ nanowires and PVDF-TrFE-CFE [8342-05]

H. Tang, Univ. of Florida (United States); Y. Lin, The Univ. of Texas at El Paso (United States);

H. A. Sodano, Univ. of Florida (United States)

834207 Nano-enhanced polymer composites for energy storage applications (Best Student Paper Award) [8342-06]

A. Barhoumi Meddeb, Texas A\&M Univ. (United States); Z. Ounaies, The Pennsylvania State Univ. (United States)

834208 Preparation of reduced graphene/ PVDF nanocomposites using co-solvent approach [8342-07]

N. Sigamani, Z. Ounaies, The Pennsylvania State Univ. (United States); G. Ehlert, H. Sodano, Univ. of Florida (United States)

8342 OA Characterization of particle diameter and interphase effects on Young's modulus of $\mathrm{SiO}_{2} /$ epoxy particulate composites [8342-09]

J.-S. Jang, Univ. of Delaware (United States); R. F. Gibson, Univ. of Nevada Reno (United

States); J. Suhr, Univ. of Delaware (United States)

\section{SESSION 3 ACTIVE POLYMERS I}

8342 OC Optimizing the photomechanical performance of glassy azobenzene liquid crystal polymer networks [8342-11]

L. Cheng, Florida A\&M and The Florida State Univ. (United States); K. M. Lee, A. McClung, J. Baur, Air Force Research Lab. (United States); T. J. White, W. S. Oates, Florida A\&M and The Florida State Univ. (United States)

8342 OE Ultrasonic performance of the PVDF thin film sensors under thermal fatigue [8342-14] V. T. Rathod, D. Roy Mahapatra, Indian Institute of Science (India); A. Jain, A. Gayathri, National Aserospace Labs. (India) 
8342 OF Electrospun porous conductive polymer membranes [8342-15]

J. Wang, H. E. Naguib, A. Bazylak, Univ. of Toronto (Canada)

\section{SESSION 4 MODELING OF PIEZOELECTRIC CERAMICS}

$8342 \mathrm{OH} \quad$ Harmonic electro-optic modulation using relaxor ferroelectric PLZT ceramics [8342-18]

R. G. Sabat, Royal Military College of Canada (Canada)

\section{SESSION $5 \quad$ PIEZOELECTRIC MATERIALS}

8342 OK Sliding mode control design for hysteretic ferroelectric materials [8342-21]

J. A. McMahan, R. C. Smith, North Carolina State Univ. (United States)

$8342 \mathrm{OL} \quad$ In situ polarization of polymer films in microsensors [8342-22]

M. Kranz, EngeniusMicro, LLC. (United States); M. G. Allen, Georgia Institute of Technology

(United States); T. Hudson, U.S. Army Aviation and Missile Command (United States)

\section{SESSION $6 \quad$ PIEZOELECTRIC CERAMICS: FABRICATION AND PERFORMANCE}

$8342 \mathrm{ON} \quad$ Electrical properties and sensing ability of novel piezoelectric ceramic fibers with Pt core [8342-24]

J. Du, J. Qiu, K. Zhu, H. Ji, H. Zhao, Nanjing Univ. of Aeronautics and Astronautics (China)

834200 Overcoming hysteresis in multilayered piezoceramic actuators used in adaptive optics [8342-25]

E. Bryce, E. Uzgur, D. Hutson, K. Kirk, Univ. of the West of Scotland (United Kingdom);

M. Strachan, Heriot Watt Univ. (United Kingdom); N. Schwartz, P. Parr-Burman, The Royal

Observatory, Edinburgh (United Kingdom)

\section{SESSION $7 \quad$ ACTIVE COMPOSITES II}

8342 OS Electro-mechanical characterization of structural supercapacitors [8342-83]

T. Gallagher, D. LaMaster, C. Ciocanel, C. Browder, Northern Arizona Univ. (United States)

8342 OT Toughening mechanisms of thermoplastic particulate polycarbonate composites [8342-72] H. Kim, W. Zhao, J. Suhr, Univ. of Deleware (United States)

8342 OU An experimental study of the self-healing behavior of ionomeric systems under ballistic impact tests [8342-29]

A. M. Grande, S. Coppi, L. Di Landro, G. Sala, Politecnico di Milano (Italy); C. Giacomuzzo, A. Francesconi, Univ. of Padova (Italy); M. A. Rahman, Univ. of Brescia (Italy)

8342 OV Mechanical properties of continuously reinforced MWCNT polymer composites in compression [8342-31]

Y. Li, J. Suhr, Univ. of Delaware (United States)

8342 OW Intelligent energy dissipation capability of CNTs based nanofluid [8342-85]

X. XU, H. Li, T. Shi, Harbin Institute of Technology (China) 
8342 OY Design of a deployable structure with shape memory polymers (Invited Paper) [8342-32] J. Rossiter, F. Scarpa, Univ. of Bristol (United Kingdom); K. Takashima, Kyushu Institute of Technology (Japan); P. Walters, Univ. of the West of England (United Kingdom)

$83420 Z$ Fabrication of sub-micron unidirectional patterns on SMP substrates [8342-33]

Z. Chen, S. Krishnaswamy, Northwestern Univ. (United States)

834210 Modified shape memory cyanate polymers with a wide range of high glass transition temperatures [8342-34]

F. Xie, L. Huang, Y. Liu, J. Leng, Harbin Institute of Technology (China)

\section{SESSION 9 SMP: MODELING}

834211 Analysis of the shape-recovery performance of thermally-activated shape-memory polymer composite with microstructural heterogeneities [8342-35]

M. Nishikawa, M. Hojo, Kyoto Univ. (Japan)

834212 Tailoring the time-dependent recovery of shape memory polymers [8342-36] C. Azra, C. J. G. Plummer, J.-A. E. Månson, Ecole Polytechnique Fédérale de Lausanne (Switzerland)

\section{SESSION 10 SMP COMPOSITES}

834214 The relationship between constituent property and bending actuation of shape memory composites [8342-39]

P. Cortes, Youngstown State Univ. (United States) and Air Force Research Lab. (United States); A. J. W. McClung, Air Force Research Lab. (United States) and National Research Council (United States); J. Sakulich, Air Force Research Lab. (United States) and Purdue Univ. (United States); J. W. Baur, Air Force Research Lab. (United States)

834219 Significantly improving electromagnetic performance of nanopaper and its shape-memory nanocomposite by aligned carbon nanotubes [8342-43]

H. Lu, Harbin Institute of Technology (China); J. Gou, Univ. of Central Florida (United States)

$83421 \mathrm{~A}$ Mechanical and electrical properties of spandex reinforced GMWNT/epoxy shape memory composites [8342-30]

J. Sun, Y. XU, Y. Chen, Y. Liu, J. Leng, Harbin Institute of Technology (China)

\section{SESSION 11 MAGNETO-ACTIVE MATERIALS}

8342 1B Microstructure-based modeling of magneto-rheological elastomers [8342-86]

Y. Han, Z. Zhang, lowa State Univ. (United States); L. E. Faidley, Wartburg College (United States); W. Hong, lowa State Univ. (United States)

8342 1C Experimental results for the behavior of MSMAs subjected to loads seen in power harvesting applications and complex loads [8342-46]

C. Ciocanel, H. P. Feigenbaum, Northern Arizona Univ. (United States) 
$83421 \mathrm{~F} \quad$ Computational micromechanics modeling of piezoresistivity of carbon nanotube polymer nanocomposites [8342-49]

X. Ren, G. D. Seidel, Virginia Polytechnic Institute and State Univ. (United States)

8342 1G Investigation of aligned carbon nanotube architectures to understand the actuation mechanism [8342-50]

S. Geier, J. Riemenschneider, T. Mahrholz, P. Wierach, Deutsches Zentrum für Luft- und Raumfahrt e.V. (Germany); M. Sinapius, Technical Univ. of Braunschweig (Germany)

$83421 \mathrm{H} \quad$ Autonomous sensing of composites with carbon nanotubes for structural health monitoring [8342-51]

Y. Liu, M. Yekani Fard, Arizona State Univ. (United States); A. Rajadas, McClintock High

School (United States); A. Chattopadhyay, Arizona State Univ. (United States)

\section{SESSION 13 SMA: EXPERIMENTAL}

$834211 \quad$ Lowering the power consumption of Ni-Ti shape memory alloy [8342-52]

A. Villanueva, S. Gupta, S. Priya, Virginia Polytechnic Institute and State Univ. (United States)

$83421 \mathrm{~J} \quad$ Stress-induced tuning of ultrasonic additive manufacturing Al-NiTi composites [8342-53] R. Hahnlen, M. J. Dapino, The Ohio State Univ. (United States)

8342 IK An innovative approach to achieve re-centering and ductility of cement mortar beams through randomly distributed pseudo-elastic shape memory alloy fibers [8342-54] N. Shajil, S. M. Srinivasan, M. Santhanam, Indian Institute of Technology Madras (India)

\section{SESSION 14 SMA: MODELING AND CHARACTERIZATION}

$83421 \mathrm{M}$ Phenomenological modeling of induced transformation anisotropy in shape memory alloy actuators [8342-56]

D. J. Hartl, Texas A\&M Univ. (United States); A. Solomou, Univ. of Patras (Greece);

D. C. Lagoudas, Texas A\&M Univ. (United States); D. Saravanos, Univ. of Patras (Greece)

$83421 \mathrm{~N} \quad$ Modeling and Bayesian parameter estimation for shape memory alloy bending actuators [8342-57]

J. H. Crews, R. C. Smith, North Carolina State Univ. (United States)

834210 A closed-form solution for superelastic shape memory alloy beams subjected to bending [8342-58]

R. Mirzaeifar, R. DesRoches, A. Yavari, K. Gall, Georgia Institute of Technology (United States)

8342 IP Evolution of phase transformation and reorientation during stress arrest in shape memory alloys [8342-59]

V. R. Russalian, A. Bhattacharyya, Univ. of Arkansas at Little Rock (United States) 
8342 IR Development of thermoplastic coated multifunctional transmission elements [8342-61]

B. Golaz, V. Michaud, Ecole Polytechnique Fédérale de Lausanne (Switzerland);

R. de Oliveira, BAM Federal Institute for Materials Research and Testing (Germany);

J.-A. E. Månson, Ecole Polytechnique Fédérale de Lausanne (Switzerland)

8342 is Vibration and wave number characterization in carbon-fiber sandwich composite structures [8342-62]

J. Sargianis, J. Suhr, Univ. of Delaware (United States)

8342 iT Enhancement of impact-induced mechanoluminescence for structure health monitoring using swift heavy ion irradiation [8342-66]

T. Z. Zhan, Kyushu Univ. (Japan); C. N. Xu, Kyushu Univ. (Japan) and National Institute of Advanced Industrial Science and Technology (Japan) and CREST, Japan Science and Technology Agency (JST) (Japan); H. Yamada, Kyushu Univ. (Japan) and National Institute of Advanced Industrial Science and Technology (Japan); Y. Terasawa, Kyushu Univ. (Japan); L. Zhang, National Institute of Advanced Industrial Science and Technology (Japan); H. Iwase, M. Kawai, High Energy Accelerator Research Organization (Japan)

$83421 \mathrm{~S} \quad$ Study on a new concept of multi-stable lattice structure [8342-63]

F. Dai, H. Li, S. Du, Harbin Institute of Technology (China)

$83421 \mathrm{~V}$ Fabrication and EM shielding properties of electrospining PANi/MWCNT/PEO fibrous membrane and its composite [8342-65]

Z. Zhang, X. Jiang, Y. Liu, J. Leng, Harbin Institute of Technology (China)

\section{POSTER SESSION}

8342 IW Towards auxetic nanofibres: molecular modelling of auxetic behaviour in cellulose II [8342-12]

Y. T. Yao, Harbin Institute of Technology (China) and The Univ. of Bolton (United Kingdom);

A. Alderson, K. L. Alderson, The Univ. of Bolton (United Kingdom)

$83421 \mathrm{X} \quad$ Aluminum oxide particle optical constant in high temperature [8342-38]

J. Yin, Harbin Univ. of Science and Technology (China)

8342 1Y A study of characteristics of cellulose-based nano composite [8342-67]

C. Yang, Andong National Univ. (Korea, Republic of); J. Kim, Inha Univ. (Korea, Republic of)

834212 Determination of local debonding stress and investigation of its effect on mechanical properties of glass short fiber reinforced polycarbonate composites [8342-68]

W. Zhao, H. Kim, J. Suhr, Univ. of Delaware (United States)

834220 Temperature tuning of band-structure of 1D periodic elastic composites [8342-69] H. Sadeghi, A. Srivastava, R. Griswold, S. Nemat-Nasser, Univ. of California, San Diego (United States)

834222 Fabrication of grape-like structures with micro capsule covering metal powder, and application to novel porous metal [8342-73]

S. Asano, T. Makuta, G. Murasawa, Yamagata Univ. (Japan) 
834225 Analysis of functionally graded piezoelectric plates in actuator mode [8342-77]

R. G. Reid, R. Paskaramoorthy, Univ. of the Witwatersrand (South Africa)

834227 Mechanical vibration induced electro-spinning of polyvinylidene difluoride (PVDF)

[8342-80]

K. S. Moon, K. Morsi, S. K. Kassegne, A. Sepehri, T. Murray, San Diego State Univ. (United States)

834228 Characterization of friction joints subjected to high levels of random vibration [8342-81] O. de Santos, P. MacNeal, Jet Propulsion Lab. (United States)

834229 Applications of multifunctional polymer-matrix composites in hybrid heat sinks [8342-82] S. N. Leung, O. M. Khan, H. E. Naguib, F. Dawson, Univ. of Toronto (Canada); V. Adinkrah, AEG Power Solutions Inc. (Canada)

Author Index 


\title{
Conference Committee
}

\author{
Symposium Chairs
}

Norbert G. Meyendorf, Fraunhofer-Institut für Zerstörungsfreie

Prüfverfahren (Germany) and University of Dayton (United States)

Norman M. Wereley, University of Maryland, College Park

(United States)

Symposium Cochairs

Victor Giurgiutiu, University of South Carolina (United States)

Christopher S. Lynch, University of California, Los Angeles

(United States)

Conference Chair

Nakhiah C. Goulbourne, University of Michigan (United States)

Conference Cochair

Zoubeida Ounaies, The Pennsylvania State University (United States)

Program Committee

Jayasimha Atulasimha, Virginia Commonwealth University (United States)

Abhijit Bhattacharyya, University of Arkansas at Little Rock

(United States)

Gregory P. Carman, University of California, Los Angeles (United States)

Pavel M. Chaplya, Sandia National Laboratories (United States)

Constantin Ciocanel, Northern Arizona University (United States)

Marcelo J. Dapino, The Ohio State University (United States)

LeAnn E. Faidley, lowa State University (United States)

Daniel J. Inman, Virginia Polytechnic Institute and State University (United States)

Marc Kamlah, Karlsruher Institut für Technologie (Germany)

Haluk E. Karaca, University of Kentucky (United States)

Ibrahim Karaman, Texas A\&M University (United States)

Kwang J. Kim, University of Nevada, Reno (United States)

Dimitris C. Lagoudas, Texas A\&M University (United States)

Chad M. Landis, The University of Texas at Austin (United States)

Kam K. Leang, University of Nevada, Reno (United States)

Donald J. Leo, Virginia Polytechnic Institute and State University

(United States) 
Jiangyu Li, University of Washington (United States)

Sergio Luis dos Santos e Lucato, Teledyne Scientific Company (United States)

Christopher S. Lynch, University of California, Los Angeles (United States)

Karla M. Mossi, Virginia Commonwealth University (United States)

Robert C. O'Handley, Massachusetts Institute of Technology (United States)

Etienne Patoor, Université de Metz (France)

Ralph C. Smith, North Carolina State University (United States)

Jonghwan Suhr, University of Delaware (United States)

Vishnu Baba Sundaresan, Virginia Commonwealth University (United States)

\section{Session Chairs}

1 Ferroelectric Materials

Pavel M. Chaplya, Sandia National Laboratories (United States)

Ribal G. Sabat, Royal Military College of Canada (Canada)

Christopher S. Lynch, University of California, Los Angeles

(United States)

2 Active Composites I

William S. Oates, The Florida State University (United States)

Marc Kamlah, Karlsruher Institut für Technologie (Germany)

3 Active Polymers 1

Henry Sodano, University of Florida (United States)

Kwang J. Kim, University of Nevada, Reno (United States)

$4 \quad$ Modeling of Piezoelectric Ceramics

Vishnu Sundaresan, Virginia Polytechnic Institute and State University (United States)

Jonghwan Suhr, University of Delaware (United States)

5 Piezoelectric Materials

Constantin Ciocanel, Northern Arizona University (United States)

6 Piezoelectric Ceramics: Fabrication and Performance

Zoubeida Ounaies, The Pennsylvania State University (United States)

Sergio Luis dos Santos e Lucato, Teledyne Scientific Company (United States)

$7 \quad$ Active Composites II

Jonghwan Suhr, University of Delaware (United States)

Kam K. Leang, University of Nevada, Reno (United States) 
8 SMP: Fabrication and Characterization

Jayasimha Atulasimha, Virginia Commonwealth University

(United States)

9 SMP: Modeling

Pedro Cortes, Youngstown State University (United States)

10 SMP Composites

Darren Hartl, Texas A\&M University (United States)

Gary D. Seidel, Virginia Polytechnic Institute and State University (United States)

11 Magneto-active Materials

Abhijit Bhattacharyya, University of Arkansas at Little Rock

(United States)

12 CNT-based Multifunctional Materials

Hani Naguib, University of Toronto (Canada)

13 SMA: Experimental

Marcelo J. Dapino, The Ohio State University (United States)

Gary D. Seidel, Virginia Polytechnic Institute and State University (United States)

14 SMA: Modeling and Characterization

Nakhiah C. Goulbourne, University of Michigan (United States)

Dimitris C. Lagoudas, Texas A\&M University (United States)

15 Multifunctional Composites and Metamaterials

Hani Naguib, University of Toronto (Canada)

Nakhiah C. Goulbourne, University of Michigan (United States) 
Downloaded From: https://www.spiedigitallibrary.org/conference-proceedings-of-spie on 25 Apr 2023

Terms of Use: https://www.spiedigitallibrary.org/terms-of-use 